\title{
STRATEGI PENGEMBANGAN PARIWISATA \\ DI KABUPATEN LUMAJANG \\ (Studi pada Objek Wisata Puncak B29 di Desa Argosari Kecamatan Senduro Kabupaten Lumajang)
}

\author{
Oleh: Betty Triana Kartika Wiyati \\ Universitas Jember \\ email: ega.deva2407@gmail.com
}

Recived: 24 Januari 2018, Revised: 8 Februari 2018, Accepted: 24 Februari 2018

\begin{abstract}
Abstrak
Hasil penelitian ini disimpulkan bahwa objek wisata Puncak B29 yang terletak di Desa Argosari saat ini menjadi salah satu objek wisata prioritas di Kabupaten Lumajang. Keberadaannya sangat memberi peluang untuk dapat mengangkat perekonomian masyarakat sekitar dan menambah PAD Kabupaten Lumajang. Oleh karena itu pemerintah Kabupaten Lumajang melalui Dinas Pariwisata Dan Kebudayaan melakukan strategi pengembangan terhadap kawasan B29. Pengembangan terhadap kawasan B29 hanya dilakukan dari segi fisik saja. Sedangkan pengembangan terhadap unsur yang lain masih kurang. Hal ini disebabkan karena kurang maksimalnya pemberdayaan masyarakat setempat dalam usaha jasa pariwisata, kurang harmonisnya hubungan antara Kepala Desa Argosari dan ketua kelompok sadar wisata Desa Argosari serta tidak adanya regulasi khusus yang mengatur tentang pengelolaan objek wisata Puncak B29. Sehingga perolehan PAD belum jelas.

Kata kunci: Strategi pengembangan, pariwisata
\end{abstract}

\begin{abstract}
The results of this study concluded that the object of Peak B29 located in Argosari Village is currently one of the priority tourism object in Lumajang Regency. Its existence is very giving opportunities to be able to lift the economy of the surrounding community and increase PAD Lumajang District. Therefore the government of Lumajang Regency through the Department of Tourism and Culture undertook the development strategy towards the region B29. Development of the B29 region is only done from the physical side only. While the development of other elements is still lacking. This is due to the lack of maximum local community empowerment in tourism service business, less harmonious relationship between Head of Argosari Village and head of conscious group of tourism Argosari Village and the absence of special regulation which regulate the management of Puncak B29. So the acquisition of PAD is not yet clear.

Keywords: Strategy development, tourism
\end{abstract}




\section{A. Pendahuluan}

Objek wisata yang dimiliki Kabupaten Lumajang sebagian besar adalah wisata alam, salah satunya adalah Puncak B29.Puncak B29 ini merupakan salah satu objek wisata yang berada di Desa Argosari Kecamatan Senduro Kabupaten Lumajang yang jaraknya kurang lebih $40 \mathrm{~km}$ dari Ibukota Kabupaten Lumajang.Kawasan objek wisata Puncak B29 memiliki daya tarik wisata alam yang didukung oleh keunikan keindahan alam dan kekhasan suku Tenggernya.Disebut B29 karena merupakan singkatan dari Bukit 29 yang artinya bukit yang ketinggiannya mencapai 2.900 meter dari permukaan laut.

Menurut pernyataan Edi Prakoso, SE selaku Kepala UPT Dinas Pariwisata dan Kebudayaan Kabupaten Lumajang saat wawancara pada tanggal 10 Maret 2017, beberapa wisatawan menjuluki tempat ini sebagai "negeri diatas awan". Hal ini dikarenakan setelah matahari terbit secara perlahan-lahan akan muncul awan putih di sekitar bukitsehingga tempat wisatawan berdiri berada sejajar atau diatas awan tersebut.Jadiwisatawan seperti berdiri diantaragumpalan awan putih yang sangat indah dan Dinas Pariwisata dan Kebudayaan Kabupaten Lumajang menggunakan kalimat, "negeri diatas awan" sebagai brand imageB29.

Wisata B29 tidak hanya menyuguhkan keindahan alamnya, tapi juga menyuguhkan pesona kearifan lokal suku Tengger yang merupakan penduduk Desa Argosari, untuk itu dibawah pembinaan Dinas Pariwisata Dan Kebudayaan Kabupaten Lumajang dibentuklah paguyuban tukang ojek B29 guna menyamakan tarif.Semua tukang ojek yang menarik penumpang ke puncak B29 didata dan diberi baju rompi sebagai seragam paguyuban.Wisatawan dikenakan tarif sebesar Rp. 75.000 sudah termasuk tiket masuk, parkir dan ongkos tukang ojek dari area parkir ke puncak B29 pulang pergi.

Berdasarkan penuturan Kepala Desa Argosari Ismail bahwa awal dikenal sekitar tahun 2013 akses jalan menuju Puncak B29 masih ala kadarnya, berupa jalan setapak yang hanya cukup dilewati satu kendaraan roda dua saja. Jalan setapak ini biasa dilewati oleh para petani suku Tengger ketika mereka sedang menuju ladangnya masing-masing.Bagi suku Tengger melewati jalan setapak yang bergelombang, berkelok-kelok dan menanjak ini tidak sulit karena mereka 
sudah terbiasa berjalan kaki.Jalan seperti inibagi para wisatawan merupakan medan yang penuh tantangan dan memicu adrenaline. Para wisatawan yang kurang mahir mengendarai kendaraan roda dua, sebaiknya menggunakan jasa tukang ojek untuk mencapai Puncak B29 karena mengendarai kendaraan roda dua sendiri dapat beresiko kecelakaan.Track ke Puncak B29 waktu itu memang hanya diperuntukkan untuk wisatawan yang suka tantangan alam, kurang tepat untuk wisata keluarga.

Wisatawan banyak yang belum mengetahui beberapa objek wisata yang bisa dikunjungi di kawasan objek wisata Desa Argosari ini. Hal ini karena tidak ada guide yang standby di kawasan objek wisata tersebut. Selain itu tidak adanya promosi tentang objek wisata pendukung selain Puncak B29 sebagai "negeri diatas awan."Hal ini juga harus menjadi perhatian pemerintah Kabupaten Lumajang.

Tarif ojek telah ditetapkan melalui Peraturan Desa Argosari Nomor 3 Tahun 2016, namun pada kenyataannya tukang ojek di kawasan objek wisata Puncak B29 masih ada yang mengenakan tarif sesukanya kepada para wisatawan. Tarif yang dikenakan bervariasi, mulai dari Rp. 60.000 sampai dengan Rp. 100.000 dan mereka tidak dikenai sanksi, sementara berdasarkan Peraturan Desa Argosari Nomor 3 Tahun 2016 disebutkan bahwa semua tukang ojek yang melanggar atas penarikan tarif ini akan dikenakan sanksi berupa denda 10 sak semen untuk pembangunan desa. Hal ini dikarenakan kurangnya pengawasan dan tidak adanya tindakan yang tegas baik dari pemerintah Desa Argosari maupun pemerintah Kabupaten Lumajang. Dengan adanya tarif yang bervariasi ini dapat menyebabkan para wisatawan malas untuk berkunjung lagi ke Puncak B29 dan kunjungan wisatawan akan turun.

Dalam rangka untuk mewujudkan pembangunan dan mengembangkan desa wisata diperlukan perencanaan yang komprehensif dalam bentuk master plan (rencana induk) pada masing-masing desa wisata. Pembangunan desa wisata dilaksanakan secara terpadu melalui program dan kegiatan dari masing-masing SKPD terkait.Pemerintah daerah Kabupaten Lumajang melalui Dinas Pariwisata Dan Kebudayaan telah membuat strategi guna 
pengembangan pariwisata di Kabupaten Lumajang, namun strategi ini belum mampu memberi kemajuan yang signifikan dalam mengoptimalkan potensi yang ada. Hal ini disebabkan karena belum dilibatkannya masyarakat lokal secara maksimal dan jarangnya ditampilkan atraksi yang variatif, sehingga untukmengoptimalkan potensi yang ada serta meningkatkan kunjunganwisatawan khususnya wisatawan manca negara diperlukan strategi lain dalam upaya untukmengembangkan sektor pariwisata di Kabupaten Lumajang.

Strategiini dijaring melalui persepsi wisatawan dan masyarakat lokal sertadiharapkan mampu mengoptimalkan dan menjawab kebutuhan wisatawanserta dapat meningkatkan pendapatan masyarakat lokal, disamping tetapmempertahankan keberlangsungan dalam pembangunan pariwisata, dalam penelitian ini, penulis hanya fokus pada usaha-usaha pengembangan yang dilakukan oleh Dinas Kebudayaan Dan Pariwisata Kabupaten Lumajang yang sekarang berubah nama menjadi Dinas Pariwisata Dan Kebudayaan Kabupaten Lumajang dan kebetulan menjadi leading sector dalam pembangunan dan pengembangan desa wisata.Untuk itu penulis tertarik untuk melakukan penelitian lebih dalam mengenai hal-hal yang terkait dengan strategi pengembangan pariwisata dengan mengambil sebuah judul"Strategi Pengembangan Pariwisata di Kabupaten Lumajang" (Studi pada Objek Wisata B29 di Desa Argosari Kecamatan Senduro Kabupaten Lumajang).Tujuan dari penelitian ini adalah untuk mengungkapkan dan mengkaji lebih dalam tentang strategi pengembangan pariwisata di Kabupaten Lumajang khususnya di objek wisata B29.

\section{B. Kajian Teori}

Pengembangan pariwisata bertujuan memberikan keuntungan baik bagi wisatawan maupun warga setempat.Basis pengembangan pariwisata adalah potensi sumber daya keragaman budaya, seni dan alam (pesona alam).Pengembangan sumber daya tersebut dikelola melalui pendekatan peningkatan nilai tambah sumber daya secara terpadu antara pengembangan produk pariwisata dan pengembangan pemasaran pariwisata melalui pendekatan 
pemberdayaan masyarakat lokal dalam rangka pengembangan pariwisata (Angga, 2013:21).

Jadi, Pengembangan objek wisata dapat diartikan usaha atau cara untuk membuat jadi lebih baik segala sesuatu yang dapat dilihat dan dinikmati oleh manusia sehingga semakin menimbulkan perasaan senang dengan demikian akan menarik wisatawan untuk berkunjung.

Dalam penelitian ini juga telah dilakukan pengembangan terhadap Puncak B29 agar wisatawan tertarik untuk datang berkunjung ke Puncak B29 tersebut. Namun pengembangan yang dilakukan belum maksimal, khususnya dalam hal penyediaan souvenir, makanan khas ataupun produk unggulan setempat sebagai oleh-oleh ketika pulang ke tempat asalnya.Pemberdayaan ekonomi kreatif masyarakat setempat masih kurang maksimal.Hal ini disebabkan oleh pengetahuan tentang pengembangan pariwisata melalui usaha ekonomi kreatif di kalangan penduduk setempat masih kurang, sehingga yang dijual penduduk setempat baru terbatas pada hasil panen sayur mayur seperti kentang, daun bawang dan kubis.Sedangkan untuk makanan khas olahan Desa Argosari masih belum ada yang memasarkan. Padahal pengunjung akan merasa lebih puas jika pulang bisa membawa oleh-oleh yang menunjukkan ciri khas dari objek wisata Puncak B29. Sebab kepuasan pengunjung sangat penting guna mendukung pelaksanaan promosi objek wisata secara getoktular.

\section{Metode Penelitian}

Berdasarkan tujuan yang dikaitkan dengan topik penelitian, maka tipe penelitian ini adalah penelitian kualitatif dengan jenis deskriptifanalitis.Penelitianini dilaksanakan di Kabupaten Lumajang dengan sasaran penelitian puncak B29 yang berada di Desa Argosari Kecamatan Senduro. Sasaran penelitian ini menarik untuk dipilih oleh peneliti karena saat ini pariwisatatersebutmenjadi isu dalam mendongkrak usaha pariwisata di Kabupaten Lumajang.Fokus penelitian ini adalah strategi pengembangan pariwisata di Kabupaten Lumajang, dengan studi kasus di puncak B29. 
Pada penelitian ini, informan kunci yang ditentukan oleh peneliti adalah Kepala Bidang Destinasi Pariwisata pada Dinas Pariwisata dan Kebudayaan Kabupaten Lumajang,

Informan berikutnya adalah Kepala Bidang Pemasaran, Kepala Seksi Promosi dan Kerjasama, Kepala Seksi Jasa Usaha Pariwisata serta Kepala Seksi Kelembagaan dan SDM Kepariwisataan pada Dinas Pariwisata Dan Kebudayaan. Informan ini ditentukan karena mengetahui informasi tentang kegiatan apa saja yang dilakukan oleh Dinas Pariwisata Dan Kebudayaan dalam rangka meningkatkan kunjungan wisatawan di Kabupaten Lumajang. Untuk melengkapi informasi dan untuk mendapatkan data-data tentang pengembangan kepariwisataan, lebih lanjut peneliti disarankan untuk wawancara juga dengan staf yang menangani langsung masalah laporan data kepariwisataan, Kepala Desa Argosari dan ketua kelompok sadar wisata.

\section{Strategi Pengembangan Pariwisata di Objek Wisata Puncak B29}

Suatu daerah akan menjadi daerah tujuan wisata atau destinasi pariwisata jika pemerintah daerah melakukan banyak hal seperti: 1. Memantapkan pembangunan jalan yang dapat digunakan untuk melihat keindahan panorama alam seperti panorama pegunungan dan lembah; 2. Membangun jalan-jalan menuju pantai-pantai unggulan yang bisa dinikmati atau bisa melihat sunset; 3 . Mengembangkan seni budaya yang dipandang unik; 4. Melakukan penataan wilayah danau atau sungai yang memberikan nilai pemandangan yang memanjakan mata seperti penataan dan pengelolaan 'danau singkarak' di Padang yang didahului dengan kegiatan yang mirip tour de France di Perancis; 5. Menyelenggarakan berbagai event lomba perahu layar internasional, lomba selancar internasional dan lomba-lomba lainnya minimal tingkat nasional; 6 . Menata dan mengelola kawasan gunung dan kawasan hutan; 7. Mengembangkan budaya pemanfaatan gedung seperti masjid, gereja, pura, klenteng, vihara sebagai tempat berdoa bagi setiap umatnya atau jemaatnya pada waktu pagi, siang dan malam. Menggunakan tempat sembahyang tersebut tidak hanya pada hari tertentu atau saat ada acara-acara khusus saja, melainkan menjadikan gedung tempat 
berdoa tersebut sebagai rumah doa setiap saat bagi jemaatnya; 8. Mengembangkan dan membina desa adat atau desa wisata serta; 9.Membudayakan kebersihan dan green regency; 10.Mengembangkan pengelolaan MICE (meeting, incentives, conference and exhibition); 11.Mengusahakan ada penerbangan langsung dengan kota-kota besar di manca negara; 12.Membina dan mengembangkan perkampungan seniman, termasuk penetapan kawasan lokasi perhotelan elit; 13.Membina dan mengembangkan potensi kerajinan tangan; 14.Membina dan mengembangkan sanggar seni budaya serta karya lukisan.Pertanyaan yang mungkin muncul di benak kita adalah mengapa banyak sekali hal-hal yang harus dikerjakan oleh daerah bila menjadi daerah tujuan wisata atau destinasi pariwisata? Faktanya memang banyak yang akan dikerjakan, tetapi bila mau melaksanakan dengan baik tentu dibagi kepada Satuan Kerja Perangkat (SKPD) sesuai tugas pokok dan fungsi (tupoksi). Jadi para pemimpin di daerah, tinggal menyusun program kerja dengan penganggaran secara multiyears (Zebua, 2016).

Dinas Pariwisata dan Kebudayaan Kabupaten Lumajang juga mengembangkan salah satu dari unsur tersebut, yaitu mengembangkan sarana dan prasarana di kawasan objek wisata puncak B29 yang merupakan salah satu objek wisata prioritas di Kabupaten Lumajang.Menurut penuturan Bambang Wijanarko, Kepala Seksi Pengembangan Dinas Pariwisata dan Kebudayaan Kabupaten Lumajang, pengembangan sarana dan prasarana ini meliputi pembangunan jalan paving menuju puncak B29.Awalnya jalan setapak menuju puncak B29 hanya berupa tanah yang licin ketika hujan dan berdebu ketika kemarau.Kemudian pada awal tahun 2016 mulailah dibangun jalan paving menuju puncak.Pembangunan jalan paving ini tidak sampai puncak, melainkan hanya sampai pada radius seratus meter sebelum puncak.Akan tetapi hal ini dapat mempermudah tukang ojek ketika mereka membawa pengunjung ke puncak B29.

Masih menurut penuturan Bambang pada wawancara bulan Maret 2017, untukmembangun sarana dan prasarana berikutnya, yaitu rest area I dan rest area II dibutuhkan tanah yang harus dibeli dari penduduk setempat dan itu tidak mudah. Oleh karena itu Dinas Pariwisata Dan Kebudayaan Kabupaten Lumajang meminta bantuan kepada Kepala Desa Argosari untuk menjadi penghubung 
komunikasi dengan pemilik tanah.Menurut pernyataan Kepala Desa Argosari Ismail, "beli tanah di sini itu tidak mudah.Pendatang banyak yang mau beli buat usaha, tapi selalu ditolak.Kalau untuk kepentingan umum, biasanya boleh. Tapi untuk "ndadekno" tanah di rest area I ini saya "nglakoni" puasa selama empat puluh hari."

Pada akhirnya tanah untuk pembangunan rest area $I$ berhasil dibeli oleh pemerintah Kabupaten Lumajang melalui Dinas Pariwisata Dan Kebudayaan Kabupaten Lumajang dari warga Desa Argosari yang bernama Sukis dengan harga enam ratus juta rupiah. Sedangkan tanah untuk pembangunan rest area II dibeli dari dua orang, warga Desa Ranupane dan warga Desa Argosari seharga empat ratus juta rupiah. Proses pembeliannya lebih mudah dibandingkan dengan pembelian tanah untuk pembangunan rest area $I$.

Sedangkan pada pembangunan rest area II dibagi menjadi dua bagian, sisi kanan menggunakan anggaran dari dana alokasi khusus (DAK) yang meliputi; pembangunan ruang pengelola, pembangunan kamar mandi, pembangunan pagar lampu, pembangunan sculpture bamboo, pembangunan gerbang daun, pembangunan gazebo daun, pembangunan tenda kemah dan pembangunan bangunan penunjang. Pembangunan sisi kiri menggunakan dana alokasi umum (DAU) yang meliputi; pembangunan gazebo, pembangunan gerbang foto, pembangunan pos ojek, pembangunan parkiran serta pekerjaan listrik dan pertamanan (Master Plan Dinas Pariwisata dan Kebudayaan Kabupaten Lumajang).

Dengan selesainya pembangunan rest area I dan rest area II diharapkan dapat meningkatkan perekonomian penduduk Desa Argosari dan sekitarnya. Sebab semua pengunjung B29 parkirnya akan diarahkan ke rest area I, sehingga pengunjung bisa istirahat sejenak sambil belanja makanan atau souvenir yang dijual di kios-kios yang ada didalam rest area $I$.

Berdasarkan penuturan Bagus Williargo staf Bidang Pemasaran pada Dinas Pariwisata dan Kebudayaan Kabupaten Lumajang, untuk meningkatkan kunjungan di B29, Dinas Pariwisata Dan Kebudayaan Kabupaten Lumajang sejak tahun 2015 menyelenggarakan Festival Tengger.Festival tengger ini dilaksanakan 
satu kali dalam setahun.Pada tanggal 7 Mei 2017 bekerjasama dengan para seniman yang se- Jawa Bali menyelenggarakan event "Menari Diatas Awan" yang diikuti oleh para seniman tari yang ada di seluruh Indonesia. Bahkan ada beberapa dari luar negeri.Mereka unjuk kemampuan seni tari modern dan kontemporer yang pelaksanaannya berada di puncak B29.Tujuan mereka selain untuk mengembangkan potensi diri, juga membantu pemerintah Kabupaten Lumajang untuk menarik minat wisatawan untuk berkunjung ke Kabupaten Lumajang khususnya di puncak B29.

Promosi juga merupakan unsur yang penting dalam mengembangkan pariwisata. Semakin gencar kita melakukan promosi, maka objek wisata yang kita perkenalkan akan semakin dikenal oleh banyak orang. Untuk itu harus cerdik dalam menggunakan media untuk melakukan promosi, agar orang tertarik dan penasaran ingin datang ke objek wisata yang kita promosikan.

Dalam hal mempromosikan puncak B29, Dinas Pariwisata Dan Kebudayaan Kabupaten Lumajang telah melakukan berbagai hal, yaitu dengan menyelenggarakan atraksi seperti "Festival Tengger" dan "Menari Diatas Awan" serta mengikuti pameran MTF (Majapahit Travel Fair) yang diselenggarakan oleh Dinas Pariwisata Dan Kebudayaan Provinsi Jawa Timur yang dilaksanakan setiap satu tahun sekali. Pada tahun 2015 juga pernah mengikuti Pameran Bittex di Bali. Pada event pameran ini, Dinas Pariwisata Dan Kebudayaan Kabupaten Lumajang menayangkan video tentang keindahan puncak B29 di stan pamerannya. Selain itu juga membagi-bagikan pamphlet dan leaflet tentang objek wisata yang ada di Kabupaten Lumajang termasuk puncak B29 kepada seluruh pengunjung pameran, seluruh agen perjalanan (biro travel) yang ada di Kabupaten Lumajang dan ke dua belas hotel dan penginapan yang ada di Kabupaten Lumajang yaitu Hotel Lumajang, Hotel Gajah Mada, Hotel Prima, Hotel Grand Aloha, Hotel Aloha, Hotel Cantik, Hotel Somanake, Hotel Maharaja, Hotel Jelita, Hotel Abba, Wisma Amanda dan Losmen Baru.

Promosi pariwisata yang dilakukan oleh Dinas Pariwisata Dan Kebudayaan Kabupaten Lumajang selanjutnya melalui media cetak, media online 
dan media sosial. Melalui media cetak, bekerja sama dengan media cetak milik maskapai penerbangan nasional, seperti Garuda Airdan Lion Air.

Dinas Pariwisata Dan Kebudayaan Kabupaten Lumajang juga menyelenggarakan kegiatan widyawisata yang pesertanya berasal dari perwakilan siswa-siswa SMA, MA dan SMK yang ditunjuk oleh gurunya masingmasing.Tujuan wisatanya adalah objek wisata yang ada di Kabupaten Lumajang.Perwakilan siswa yang mengikuti widyawisata ini diberi tugas mengambil foto sebanyak-banyaknya tentang objek wisata yang dikunjunginya dan mengunggahnya di akun media sosialnya masing-masing.Kegiatan widyawisata ini dilaksanakan sekali dalam setahun.

Kegiatan promosi lainnya yang dilakukan oleh Dinas Pariwisata Dan Kebudayaan Kabupaten Lumajang adalah dengan mengikuti kegiatan FKKS (Festival Kesenian Kawasan Selatan) yang diselenggarakan oleh Dinas Pariwisata Dan Kebudayaan Provinsi Jawa Timur dan dilaksanakan setahun sekali. Peserta FKKS ini adalah Kabupaten/Kota Pasuruan, Kabupaten/Kota Probolinggo, Kabupaten/Kota Malang, Kabupaten/Kota Blitar, Kabupaten Tulungagung, Kabupaten Lumajang, Kabupaten Jember, Kabupaten Bondowoso, Kabupaten Situbondo dan Kabupaten Banyuwangi. Masing-masing daerahmenampilkan kesenian yang dimilikinya serta biasanya memperkenalkan objek-objek wisata yang ada di daerahnya melalui narasi yang dibaca oleh master ceremony.Pelaksanaan FFKS ini dilaksanakan secara bergiliran di kabupaten/kota yang menjadi peserta untuk setiap tahunnya.

Meskipun Dinas Pariwisata Dan Kebudayaan Kabupaten Lumajang telah melakukan pembinaan homestay terhadap warga Desa Argosari yang siap menjadikan rumahnya untuk homestay bagi wisatawan.Pola hidup sederhana dan kurang peduli terhadap kebersihan lingkungan merupakan kendala yang mempengaruhi kesiapan mereka menerima wisatawan untuk menginap.Selain itu adanya mindset yang sudah cukup puas dengan kehidupan yang sekarang (sebagai petani lading sayur-mayur) juga merupakan faktor penghambat pengembangan pariwisata. 
Belum adanya regulasi tentang pengelolaan objek wisata puncak B29 juga merupakan faktor penghambat terhadap pengembangan objek wisata tersebut. Dengan adanya regulasi yang jelas, maka Dinas Pariwisata Dan Kebudayaan Kabupaten Lumajang akan lebih leluasa dalam mengeksplor objek wisata puncak B29. Dengan adanya regulasi yang jelas, uang yang didapat dari retribusi karcis masuk dan retribusi pedagang di area kawasan B29 dapat menambah pendapatan asli daerah Kabupaten Lumajang.

Faktor penghambat lainnya adalah adanya komunikasi yang tidak baik antara Kepala Desa Argosari dengan ketua kelompok sadar wisata Desa Argosari, sehingga mengakibatkan tidak terciptanya sinergitas antara kedua tokoh yang berperan penting dalam pengembangan objek puncak B29. Adanya komunikasi yang tidak baik ini dilandasi oleh faktor politik, adanya mindset Kepala Desa Argosari yang menganggap bahwa ketua kelompok sadar wisata akan mencalonkan diri sebagai kepala desa di tahun 2018. Sehingga setiap kali ketua kelompok sadar wisata mengadakan pertemuan dengan warga terkait dengan pengembangan objek wisata puncak B29 dibubarkan. Bahkan ketua kelompok sadar wisata pernah diciduk oleh oknumintel dari Komando Distrik Militer guna dimintai keterangan karena telah mengadakan pesamuan adat (pertemuan warga) yang tujuannya adalah untuk membahas tentang atraksi wisata yang akan disuguhkan kepada para wisatawan puncak B29. Setelah memberikan penjelasan yang sebenarnya, akhirnya ketua kelompok sadar wisata diperbolehkan pulang.

Berbagai upaya telah dilakukan oleh ketua kelompok sadar wisata agar komunikasinya dengan Kepala Desa Argosari kembali membaik, tapi tetap mendapatkan respon yang kurang baik dari Kepala Desa Argosari. Menurut penuturan Budi ketua kelompok sadar wisata Desa Argosari, bahwa dia boleh mengadakan pertemuan dengan warga asal membuat surat pernyataan bahwa dia tidak akan mencalonkan diri sebagai Kepala Desa Argosari pada tahun 2018 nanti, akan tetapi hal ini ditolak oleh Budi dengan alasan hal tersebut tidak masuk akal dan merupakan pembunuhan karakter.

Dampak dari komunikasi yang tidak baik antara pelaku pariwisata ini adalah tidak jalannya fungsi kelompok sadar wisata Desa Argosari.Padahal 
kelompok sadar wisata Desa Argosari yang diketuai oleh Budiyanto ini beranggotakan kelompok anak muda terpelajar yang ide-idenya sangat cemerlang. Diantaranya adalah Budiyanto mampu mengumpulkan pemuda-pemuda yang mempunyai sepeda motor untuk diajak menjadi tukang ojek untuk wisatawan yang akan menuju puncak B29, mampu mengumpulkan rumah yang layak dan siap untuk homestay, mampu membentuk kelompok kuliner, mampu memberdayakan pemuda-pemuda yang berada di pinggiran jauh dari objek wisata puncak B29 dan tidak terkena dampak pariwisata dicarikan orderan ojek untuk naik ke puncak B29, mampu membeli alat-alat untuk kegiatan outbond dan disewakan ke objek wisata Teluk Cinta, karena di kawasan puncak B29 masih belum ada lokasi untuk melaksanakan kegiatan outbond. Budiyanto bersama teman-teman anggota kelompok sadar wisatajuga sedang melakukan percobaan untuk membuat sambel daun bawang dan cabe terong dalam kemasan.Sejauh ini masih dalam taraf uji coba sampai seberapa lama sambel dalam kemasan ini mampu bertahan. Jadi belum sampai proses produksi dan pemasaran.

Namun karena komunikasi antara Kepala Desa Argosari dan Budiyanto selaku ketua kelompok sadar wisata kurang baik, maka masing-masing berjalan sendiri-sendiri. Tidak ada kerja sama dan sinergitas yang baik, sehingga pengembangan objek wisata puncak B29 kurang maksimal. Pada akhirnya kelompok sadar wisata vakum dan Budiyanto justru aktif dalam organisasi bentukannya sendiri, yaitu DWA (Desa Wisata Adat). Kegiatan DWA sama seperti kegiatan kelompok sadar wisata, akan tetapi dilakukan secara tidak terangterangan dan lebih mendukung kegiatan pariwisata di objek wisata Bromo. Hal ini yang menyebabkan objek wisata puncak B29 tidak akan berkembang dengan baik.

Pengembangan pariwisata pada obyek wisata di Puncak B29 khususnya pembangunan secara fisik, didukung oleh anggaran pendapatan dan belanja daerah (APBD) pemerintah Kabupaten Lumajang tahun anggaran 2016 dan APBD tahun anggaran 2017, dan akan terus dilanjutkan pada tahun anggaran berikutnya. Pemerintah Kabupaten Lumajang sangat mendukung pada kemajuan pariwisata yang ada di wilayahnya, terutama pada objek wisata yangdiprioritaskan. Objek wisata yang menjadi prioritas Kabupaten Lumajang 
pada tahun 2017 ada empat, yaitu Air Terjun Tumpak Sewu, Kebun Teh Gucialit, Ranu Kumbolo dan Puncak B29. Sedangkan pada tahun 2018 yang akan datang, yang menjadi prioritas adalah objek wisata Air Terjun Kapas Biru, Kebun Teh Gucialit, Ranu Kumbolo, Ranu Regulo, Pura Mandara Giri Semeru Agung dan Semeru.

Sumber daya manusia merupakan faktor pendukung terhadap pengembangan objek wisata Puncak B29.Dalam hal ini adalah pegawai Dinas Pariwisata Dan Kebudayaan Kabupaten Lumajang.Dengan jumlah pegawai ASN yang terbatas dan latar belakang pendidikan yang berbeda-beda, mampu bekerja dengan maksimal.

Keindahan alam menuju Puncak B29 dan moment sunrise di Puncak B29 merupakan sumber daya alam yang luar biasa.Kita tidak perlu menciptakan keindahan lagi untuk dapat dinikmati oleh para wisatawan.Potensi alam yang disuguhkan wisata Puncak B29 ini merupakan hamparan bukit dengan tumbuhan yang rindang serta hamparan ladang sayur mayur milik warga Desa Argosari yang berada pada lereng bukit dengan kemiringan yang sangat tajam. Wisatawan akan dibuat kagum oleh keindahan alam disepanjang perjalanan menuju Puncak B29. Keindahan alam inilah yang harus dijaga kelestariannya, agar mengundang kunjungan banyak wisatawan.

Berdasarkan analisa penulis, faktor pendukung yang terakhir adalah adanya hubungan yang baik antara pemerintah Desa Argosari dengan pemerintah Kabupaten Lumajang, khususnya Dinas Pariwisata Dan Kebudayaan Kabupaten Lumajang. Hal ini mempermudah proses pengembangan terhadap objek wisata Puncak B29. Hubungan baik ini membawa dampak terhadap terciptanya rasa aman bagi para wisatawan yang datang ke Puncak B29. Selain itu pemerintah Desa Argosari juga bersedia memberikan kontribusi berupa uang retribusi kepada pemerintah Kabupaten Lumajang melalui Dinas Pariwisata Dan Kebudayaan Kabupaten Lumajang yang didasarkan atas kesepakatan.

Menurut keterangan dari Kepala Desa Argosari pada wawancara bulan Mei 2017, Desa Argosari dengan pihak Perhutani, Dinas Pariwisata Dan Kebudayaan Kabupaten Lumajang dan TNBTS membahas masalah pembagian 
hasil pungutan. Perhutani minta tarif masuk untuk wisatawan nusantara sebesar sebelas ribu rupiah per orang dan TNBTS minta tujuh belas ribu per orang, namun permintaan ini ditolak oleh Kepala Desa Argosari dengan alasan memberatkan pengunjung.Selain itu pihak Perhutani dan TNBTS sampai dengan detik ini tidak pernah memberikan kontribusi pembangunan di Desa Argosari khususnya di Puncak B29.Hanya dengan Dinas Pariwisata Dan Kebudayaan Kabupaten Lumajang mau memberikan kontribusi, karena telah banyak melakukan pembangunan di Desa Argosari dan di Puncak B29.

\section{E. Kesimpulan}

Objek wisata Puncak B29 yang terletak di Desa Argosari saat ini menjadi salah satu objek wisata prioritas di Kabupaten Lumajang.Keberadaannya sangat memberi peluang untuk dapat mengangkat perekonomian masyarakat sekitar dan menambah PAD Kabupaten Lumajang.Oleh karena itu pemerintah Kabupaten Lumajang melalui Dinas Pariwisata Dan Kebudayaan melakukan strategi pengembangan terhadap kawasan B29.

Pengembangan terhadap kawasan B29 hanya dilakukan dari segi fisik saja. Sedangkan pengembangan terhadap unsur yang lain, seperti atraksi wisata masih kurang. Hal ini disebabkan karena kurang maksimalnya pemberdayaan masyarakat setempat dalam usaha jasa pariwisata, kurang harmonisnya hubungan antara Kepala Desa Argosari dan ketua kelompok sadar wisata Desa Argosari serta tidak adanya regulasi khusus yang mengatur tentang pengelolaan objek wisata Puncak B29. Sehingga perolehan PAD belum jelas..

Pemerintah Kabupaten Lumajang melalui Dinas Pariwisata Dan Kebudayaan Kabupaten Lumajang sering mengadakan kegiatan yang menunjang atraksi wisata di Puncak B29. Misalnya memfasilitasi upacara-upacara adat yang dilaksanakan oleh suku Tengger Desa Argosari atau mengadakan festival kesenian budaya lokal di Desa Argosari atau Puncak B29 setiap tiga bulan sekali. Atraksi wisata tidak hanya berupa pertunjukan kesenian budaya lokal, akan tetapi juga bisa menyuguhkan kegiatan tentang tata cara bercocok tanam ala suku Tengger 
Desa Argosari. Seperti misalnya cara bercocok tanam daun bawang di lahan miring milik petani asli suku Tengger.

Selain itu Dinas Pariwisata Dan Kebudayaan Kabupaten Lumajang harus dapat menjadi penengah atas kekurangharmonisan komunikasi antara Kepala Desa Argosari dengan ketua kelompok sadar wisata Desa Argosari, demi mewujudkan situasi yang kondusif sehingga dapat bersama-sama mengembangkan pariwisata khususnya terhadap objek wisata di Puncak B29.Pemerintah Kabupaten Lumajang harus segera membuat regulasi tentang pengelolaan objek wisata Puncak B29. Selama ini sudah ada Peraturan Daerah Kabupaten Lumajang tentang pemungutan retribusi, akan tetapi peraturan khusus tentang petunjuk pelaksanaan pengelolaan terhadap objek wisata Puncak B29 belum ada. 


\section{DAFTAR PUSTAKA}

Ali Hasan, 2015. Tourism Marketing. Yogyakarta: Center for Academic Publishing Service.

Anonim. 2017. Ekowisata Kampung Batu Malakasari. Tersedia (kampungbatu.co.id, diakses 25 Oktober 2017).

Cahyadi, B., dan Abdul K., 2015.Peranan Tata Usaha Bagian Umum Kantor Bupati Deli Serdang dalam Meningkatkan Pelayanan, Jurnal Ilmu Pemerintahan dan Sosial Politik, 1 (1): 14-24.

Deddy Prasetya Maha Rani, Pengembangan Potensi Pariwisata Kabupaten Sumenep, Madura, Jawa Timur (Studi Kasus: Pantai Lombang)Jurnal Politik Muda,Vol. 3 No. 3, Agustus-Desember 2014,412 - 421.

Damayanti,Maya, Latifah, L. 2015. Strategi Kota Pekalongan Dalam Pengembangan Wisata Kreatif Berbasis Industri Batik.Jurnal Pengembangan Kota, Home/Vol 3 No 2.

Fitrianti, Hanifa. 2014.Strategi Pengembangan Desa Wisata Talun Melalui Model Pemberdayaan Masyarakat, Economics Development Analysis Journal, Vol 3 No. 1.

Harwanto,Setyo.2014.Kajian Wisata Seni Budaya Batik Berwawasan Lingkungan Di Desa Jarum, Kecamatan Bayat, Kabupaten Klaten, Provinsi Jawa Tengah. Masters Thesis, Tata Kelola Seni ISI Yogyakarta.

Hermantoro, Henky. 2014. Creative-Based Tourism: Dari Wisata Rekreatif menuju Wisata Kreatif.Lap Lambert Academic Publishing.

Hermawan, Hary.2016. Dampak Pengembangan Desa Wisata Nglanggeran terhadap Ekonomi Masyarakat Lokal. Jurnal Pariwisata, Vol 3, No 1, pp 105-117.

2016. Dampak Pengembangan Desa Wisata Nglanggeran terhadap Sosial Budaya Masyarakat Lokal. pp. 426-35. Dalam Seminar Nasional Ilmu Pengetahuan dan Teknologi Komputer Nusa Mandiri Pertama Tahun 2016, Vol 1, pp 426-435.

2017. Pengaruh Daya Tarik Wisata, Keselamatan dan Sarana Wisata terhadap Kepuasan serta Dampaknya terhadap Loyalitas Wisatawan : Studi Community Based Tourism di Gunung Api Purba Nglanggeran. Wahana Informasi Pariwisata : Media Wisata, Vol 15, No1, pp 562-577. 
2017.Pengembangan Destinasi Wisata pada Tingkat Tapak Lahan dengan Pendekatan Analisis SWOT. Jurnal Pariwisata, Vol 4, No 2, pp 64-74.

Langgar, A. 2014.Kain Tenun NTT, Selayang Pandang. http://www.adhylanggar.info/ide/kain-tenunntt-selayang-pandang/, diakses tanggal 2 September 2014.

Lubis, A., 2014. Peran Advokat dalam Penegakan Hukum di Organisasi Asosiasi Advokat Indonesia Cabang Medan, Jurnal Ilmu Pemerintahan dan Sosial Politik, 2 (2): 191-203.

Purnawibowo, Stanov. 2014. Strategi Pengelolaan Kawasan Kota Cina, Medan, Sumatera Utara Berbasis Masyarakat.Universitas Gadjah Mada, Yogyakarta.

Victoria br. Simanungkalit, Destry Anna Sari, Frans Teguh, Hari Ristanto, Ika K, Leonardo Sambodo, Samsul Widodo, Masyhud, Sri Wahyuni, Henky Hermantoro, Henky Hermantoro, Dian Vitriani. 2015. Buku Panduan Pengembangan Desa Wisata Hijau. Jakarta: Asisten Deputi Urusan Ketenagalistrikan dan Aneka Usaha Kementerian Koperasi dan UKM Republik Indonesia.

Yahya, Arief. 2015. Sambutan Menteri Pariwisata R.I. Pada Peringatan World Tourism Day dan Hari Kepariwisataan Nasional.Tersedia (kemenpar.go.id, diakses 26 September 2017).

Zebua, Manahati. 2016. Inspirasi Pengembangan Pariwisata Daerah, Deepublish, Yogyakarta. 